\title{
1 Human motor cortical gamma activity relates to GABAergic signalling
}

\section{2 and to behaviour}

3

4 Catharina Zich*,1,2, Magdalena Nowak ${ }^{*, 1,2}$, Emily L Hinson ${ }^{1,2}$, Andrew J Quinn ${ }^{1}$, Mark W

5 Woolrich $^{1,2}$, Charlotte J Stagg ${ }^{1,2,3}$

6

$7 \quad *$ These authors contributed equally to this work.

8

$9{ }^{1}$ Oxford Centre for Human Brain Activity, Wellcome Centre for Integrative Neuroimaging, Department of Psychiatry, University of Oxford

112 Wellcome Centre for Integrative Neuroimaging, FMRIB, Nuffield Department of Clinical Neurosciences, University of Oxford

Corresponding author:

17 Catharina Zich

catharina.zich@uni-oldenburg.de

Wellcome Centre for Integrative Neuroimaging, FMRIB

20 Nuffield Department of Clinical Neurosciences

University of Oxford

\section{Keywords}

24 GABA, MEG, Motor learning, Motor system, TMS 
bioRxiv preprint doi: https://doi.org/10.1101/2021.06.16.448658; this version posted June 16, 2021. The copyright holder for this preprint (which was not certified by peer review) is the author/funder, who has granted bioRxiv a license to display the preprint in perpetuity. It is made available under aCC-BY-ND 4.0 International license.

Gamma and GABA in Human Motor Cortex

Zich \& Nowak et al.

\section{Key Points}

- We combined neuroimaging (i.e. MEG) and non-invasive brain stimulation (i.e. TMS) to examine the properties of $\gamma$ activity sub-bands in the primary motor cortex.

- Two distinct $\gamma$ sub-bands (slow- $\gamma$, mid- $\gamma$ ) show a movement-related increase in activity during finger movements and are characterised by distinct temporal-spectralspatial profiles.

- We found strong evidence for a positive relationship between slow- $\gamma(\sim 30-60 \mathrm{~Hz})$ peak frequency and endogenous GABA signalling during movement preparation (as assessed using the TMS-metric short interval intracortical inhibition).

\section{Abstract}

Gamma activity $(\gamma,>30 \mathrm{~Hz})$ is universally demonstrated across brain regions and species. However, the physiological basis and functional role of $\gamma$ sub-bands (slow- - , mid- $-\gamma$, fast- $\gamma$ ) have been predominantly studied in rodent hippocampus; $\gamma$ activity in the human neocortex is much less well understood.

Here we combined neuroimaging and non-invasive brain stimulation to examine the properties of $\gamma$ activity sub-bands in the primary motor cortex (M1), and their relationship to both local GABAergic activity and to motor learning. In 33 healthy individuals, we quantified movement-related $\gamma$ activity in M1 using magnetoencephalography, assessed GABAergic signaling using transcranial magnetic stimulation (TMS), and estimated motor learning via a serial reaction time task.

We characterised two distinct $\gamma$ sub-bands (slow- - , mid- - ) which show movement-related increase in activity during unilateral index finger movements and are characterised by distinct temporal-spectral-spatial profiles. Bayesian correlation analysis revealed strong evidence for a positive relationship between slow- $\gamma(\sim 30-60 \mathrm{~Hz})$ peak frequency and endogenous GABA signalling during movement preparation (as assessed using the TMS-metric short interval intracortical inhibition). There was also moderate evidence for a relationship between power of the movement-related mid- $\gamma$ activity $(60-90 \mathrm{~Hz})$ and motor learning. These relationships were neurochemically- and frequency-specific.

These data provide new insights into the neurophysiological basis and functional roles of $\gamma$ activity in human M1 and allow the development of a new theoretical framework for $\gamma$ activity in the human neocortex. 
bioRxiv preprint doi: https://doi.org/10.1101/2021.06.16.448658: this version posted June 16 2021. The copyright holder for this preprint (which was not certified by peer review) is the author/funder, who has granted bioRxiv a license to display the preprint in perpetuity. It is made available under aCC-BY-ND 4.0 International license.

Gamma and GABA in Human Motor Cortex

Zich \& Nowak et al.

\section{Significance Statement}

2 Gamma $(\gamma)$ activity is ubiquitous in the brain, yet our understanding of the mechanisms and

3 function of $y$ activity in the human neocortex, and particularly in the human motor cortex, is

4 limited. Using a multimodal approach, we characterised two patterns of movement-related $\gamma$

5 activity in the human motor cortex (slow- $\gamma$ and mid- - ), with different spatial, temporal and

6 spectral properties. Slow- $\gamma$ peak frequency was correlated to local GABA-A activity, whereas

7 mid-gamma power predicted performance in a subsequent motor learning task. Based on

8 these findings and previous research, we propose a theoretical framework to explain how

9 human motor cortical $\gamma$ activities may arise and their potential role in plasticity and motor

10 learning, providing new hypotheses to be tested in future studies. 
bioRxiv preprint doi: https://doi.org/10.1101/2021.06.16.448658; this version posted June 16, 2021. The copyright holder for this preprint (which was not certified by peer review) is the author/funder, who has granted bioRxiv a license to display the preprint in perpetuity. It is made available under aCC-BY-ND 4.0 International license.

Gamma and GABA in Human Motor Cortex

Zich \& Nowak et al.

\section{Introduction}

Activity within the gamma band $(\gamma,>30 \mathrm{~Hz})$ is ubiquitous across the mammalian brain. This broad frequency band is commonly divided into three sub-bands: slow- $\gamma$ (human: $\sim 30-60 \mathrm{~Hz}$ : rodent: $\sim 30-50 \mathrm{~Hz}$ ), mid- $\gamma$ (human: $\sim 60-90 \mathrm{~Hz}$; rodent: $\sim 50-100 \mathrm{~Hz}$ ) and fast- $\gamma$ (human: $>90 \mathrm{~Hz}$; rodent: $>100 \mathrm{~Hz}$ ). To date, $\gamma$ activity has been mainly explored in rodent hippocampus, where the sub-bands of this activity arise from separate locations (Schomburg et al., 2014; Lasztóczi and Klausberger, 2016), reflect distinct microcircuits (Bragin et al., 1995; Colgin et al., 2009; Fernández-Ruiz et al., 2017), and have different functional roles (Carr and Frank, 2012; Colgin, 2015). Considerably less is known about the neurophysiological bases and functional roles of the $\gamma$ sub-bands in the human neocortex.

In the human motor system, a movement-related increase in $\gamma$ power ( $\gamma$ event-related synchronization [ $\gamma$ ERS]) has been described (Crone et al., 1998; Pfurtscheller and Lopes da Silva, 1999; Canolty et al., 2006; Cheyne et al., 2008; Muthukumaraswamy, 2010, 2011; Cheyne, 2013). This has been most frequently reported for the mid- $\nu$ band (i.e. mid- $\nu$ ERS), which occurs only during actual rather than imagined movement (Muthukumaraswamy, 2011), shows spatial specificity to the primary motor cortex (M1, (Crone et al., 2006)) and temporal specificity to the time of the movement. Mid- $\gamma$ has been suggested to play a role in afferent proprioceptive feedback or relate to more active motor control processes (Miller et al., 2010; Muthukumaraswamy, 2010), and its pro-kinetic role has been demonstrated in a number of studies (Joundi et al., 2012; Swann et al., 2016, 2018). In humans, slow- $\gamma$ has been considerably less well characterised. Only few studies have reported movement-related slow$\gamma$ activity in the M1 (Crone et al., 1998; Szurhaj et al., 2006). Their data suggested that slow- $\gamma$ has a distinct spatio-temporal profile and plays a functional role in synchronising activity of neuronal populations involved in movement.

Slow- $\gamma$ and mid- $-\gamma$ likely share some physiological similarities. Empirical animal studies and computational modelling have demonstrated that GABAergic interneuron-mediated inhibition of pyramidal cell activity generates $\gamma$ activity in $\mathrm{M} 1$ (Gonzalez-Burgos and Lewis, 2008; Sohal et al., 2009; Buzsáki and Wang, 2012). Despite initial findings in humans relating Y activity in M1 to GABA (Gaetz et al., 2011) it remains to be determined how closely these data, which arise from in vitro and invasive in vivo recordings, translate into the $\gamma$ ERS seen in 
bioRxiv preprint doi: https://doi.org/10.1101/2021.06.16.448658; this version posted June 16, 2021. The copyright holder for this preprint (which was not certified by peer review) is the author/funder, who has granted bioRxiv a license to display the preprint in perpetuity. It is made available under aCC-BY-ND 4.0 International license.

Gamma and GABA in Human Motor Cortex

Zich \& Nowak et al.

1 human electrophysiological recordings. However, given the wealth of data implicating

2 changes in M1 GABAergic activity during motor learning (Stagg et al., 2011), y activity may

3 reflect a mechanism by which decreases in local GABAergic signalling mediates behavioural

4 improvements. In line with this hypothesis, our group recently demonstrated that $75 \mathrm{~Hz} \mathrm{tACS}$

5 applied to $\mathrm{M} 1$ leads to a significant reduction in local GABA-A activity, as assessed by

6 transcranial magnetic stimulation (TMS, (Nowak et al., 2017)). Moreover, this $75 \mathrm{~Hz}$ tACS-

7 induced change in GABA-A activity was closely correlated with an individual's motor learning

8 ability.

9

10 The present study aims to investigate the relationship between M1 GABAergic signalling, M1

$11 \quad \gamma$ activity and motor learning in humans. We characterized M1 $\gamma$ activity in 33 young healthy

12 individuals during unilateral index finger movement using magnetoencephalography (MEG),

13 to address the hypotheses that an individual's M1 movement-related $\gamma$ activity is related to

14 TMS measure of local GABA-A activity and the ability to learn a motor task. 


\section{Methods}

\subsection{Participants}

33 individuals (age 24.9 years, range: $21-30$ years; 14 male) gave their informed consent to participate in the study in accordance with Central University Research Ethics Committee approval (University of Oxford; MSD-IDREC-C2-2014-026 and MSD-IDREC-C1-2015-010). All participants were right-handed as assessed by the Edinburgh Handedness Inventory (Oldfield, 1971), had no history of neurological or psychiatric disorders, no metal implants, and reported no other contraindications to TMS or MEG. A subset of these data formed part of a previous publication (Nowak et al., 2017).

\subsection{Experimental Design}

All individuals completed all parts of the study on the same day in the following order: MEG data recording during rest and during a Go/NoGo task, a motor learning task (ML) and a response time task (RT) outside the MEG, and TMS during rest and RT task (Fig. 1a).

\section{MEG data acquisition}

MEG data were acquired with a whole-head 306-channel Elekta Neuromag system (204 planar gradiometers, 102 magnetometers). Concurrent surface electromyography (EMG) of the right extensor digitorum communis and first dorsal interosseous (FDI) muscle were recorded using bipolar surface electrodes. Both MEG and EMG data were sampled at $1000 \mathrm{~Hz}$ with a bandpass filter of $0.03-330 \mathrm{~Hz}$. Head position was continuously monitored with respect to the MEG sensors using four head-position (HPI) coils. The locations of HPI coils and of three anatomical fiducials (the nasion and two preauricular points) were digitized using a 3D tracking system (Polhemus, EastTrach 3D) to define the subject-specific cartesian head coordinate system. In addition, vertical and horizontal electrooculogram electrodes were used to allow for detection and removal of eye-blink artefacts. MEG data were acquired during a Go/NoGo task. A blue circle cue, presented for $200 \mathrm{~ms}$, instructed participants to prepare for an abduction of the index finger of their right hand. The cue was then replaced by a fixation cross for $1000 \mathrm{~ms}$ (cue - stimulus interval). A subsequent visual stimulus presented for $200 \mathrm{~ms}$ (coloured circle: green for Go or red for NoGo) indicated whether they should perform (Go) or withhold (NoGo) the prepared response. Participants were instructed to respond as quickly as possible on the Go trials. The stimulus was then replaced by a fixation cross for a duration that varied randomly 
1 between 2000 and 4000 ms (inter-trial interval). The task consisted of a total of 70 trials and

2 lasted $\sim 5 \mathrm{~min}$. NoGo trials (20\% of all trials) were introduced to encourage participants'

3 attention to the task. Stimuli were generated using the MATLAB Psychophysics Toolbox version 3.0 package (Brainard, 1997) and back-projected (Panasonic DLP Projector, PT D7700E) onto a screen at a viewing distance of $120 \mathrm{~cm}$ with a spatial resolution of 1024 by 768 pixels and a refresh rate of $60 \mathrm{~Hz}$.

Outside the MEG, individuals performed a visually cued motor sequence learning task which has been described previously (Nowak et al., 2017). Briefly, individuals were presented with four horizontal bars on a screen, each of which corresponded to a key on the keyboard. When a bar changed into an asterisk, individuals were instructed to press the corresponding key as quickly and accurately as possible. The task included sequence blocks consisting of three repeats of a 10-item sequence. The first and 15th blocks consisted of 30 visual cues presented in a random order. Individuals performed also a simple RT task consisting of 20 trials to characterize their individual RT for the subsequent TMS measurement. Individuals were instructed to respond to a visual Go signal (coloured green circle) by performing an index finger abduction of the right hand as quickly as possible. Visual stimuli appeared at random intervals (5-7 s) and the individuals were instructed to avoid anticipation of the Go signal and to relax their hand while the fixation cross was displayed on the screen. Stimuli were generated using the MATLAB Psychophysics Toolbox version 3.0 package (Brainard, 1997). Surface EMG was recorded via disposable neonatal ECG electrodes (Henley's Medical) from the FDI of the right hand using a belly-tendon montage with a ground electrode over the ulnar styloid process. Signals were sampled at $5 \mathrm{kHz}$, amplified, filtered $(10-1000 \mathrm{~Hz})$, and recorded using a CED 1902 amplifier, a Design). 
bioRxiv preprint doi: https//doi.org/10.1101/2021.06.16.448658; this version posted June 16, 2021. The copyright holder for this preprint (which was not certified by peer review) is the author/funder, who has granted bioRxiv a license to display the preprint in perpetuity. It is made available under aCC-BY-ND 4.0 International license.

Gamma and GABA in Human Motor Cortex

Zich \& Nowak et al.

TMS data acquisition

All TMS data were acquired using a monophasic BiStim machine connected to a $70 \mathrm{~mm}$ figureof-eight coil (Magstim). The left M1 FDI motor hotspot, i.e. the position where single-pulse motor evoked potentials (spMEPs) could be elicited in the in the right FDI muscle at the lowest stimulator intensity, was targeted. The TMS coil was held at $45^{\circ}$ to the midsagittal line with the handle pointing posteriorly. The hotspot was marked on a tight-fitting cap to ensure reproducible coil positioning. Surface EMG data were recorded in the same manner as during the RT task.

First, resting motor threshold ( $\mathrm{rMT}$ ) and active motor threshold (aMT) were determined. rMT was defined as the minimum stimulus intensity required for eliciting spMEPs of $\sim 1 \mathrm{mV}$ peakto-peak amplitude in at least 5/10 trials in the relaxed FDI muscle. aMT was defined as the minimum stimulus intensity necessary to evoke spMEPs of $\sim 200 \mu \mathrm{V}$ peak-to-peak amplitude in at least $5 / 10$ trials while individuals maintained $\sim 30 \%$ of the maximum contraction of the FDI.

Local GABA-A synaptic activity was assessed using short interval intracortical inhibition (SICl) with an interstimulus interval of 2.5 ms (Kujirai et al., 1993; Di Lazzaro et al., 2005). The conditioning stimulus was set at $70 \%$ of aMT and the test stimulus at rMT. spMEP and SICI were measured in pseudorandomized order with fifteen trials per condition, both at rest and during the pre-movement period of the simple RT task (same RT task as performed prior to TMS). TMS measures were collected at two different times during movement preparation: an early time point ( $25 \%$ of mean RT) and a late time point ( $65 \%$ of mean RT), resulting in four different pre-movement protocols: spMEP early, SpMEP late, $_{\text {SIClearly }}$ and $\mathrm{SICl}_{\text {late. }}$ The $25 \%$ and $65 \%$ RT were adjusted to each individual's mean RT according to a previously described procedure (Murase et al., 2004; Hummel et al., 2009). Fifteen trials per condition and time point were recorded.

\subsection{Data analysis}

MEG data analysis

External noise was reduced from MEG data by means of spatio-temporal signal-space separation (TSSS) and head movements (detected using HPI coils) corrected, both using 
bioRxiv preprint doi: https://doi.org/10.1101/2021.06.16.448658; this version posted June 16, 2021. The copyright holder for this preprint (which was not certified by peer review) is the author/funder, who has granted bioRxiv a license to display the preprint in perpetuity. It is made available under aCC-BY-ND 4.0 International license.

Gamma and GABA in Human Motor Cortex

Zich \& Nowak et al.

1 MaxMove software as implemented in MaxFilter version 2.1 (Elekta Neromag, Elekta,

2 Stockholm, Sweden). Further MEG data analyses were performed using the in-house OHBA

3 Software Library (OSL: https://ohba-analysis.github.io/osl-docs/) version 2.2.0. Registration between a structural MRI template, i.e. MNI152 standard-space T1-weighted average structural template image, and MEG data was performed with RHINO (Registration of Headshapes Including Nose in OSL) using nose and fiducial landmarks for coregistration and a single shell as forward model.

Continuous data were down-sampled to $500 \mathrm{~Hz}$. Further, a band-pass filter $(5-245 \mathrm{~Hz})$ and several notch filters were applied $(49-55 \mathrm{~Hz}, 99-101 \mathrm{~Hz}, 149-151 \mathrm{~Hz}, 199-201 \mathrm{~Hz})$. A wider notch filter around $50 \mathrm{~Hz}$ was used to supress $50 \mathrm{~Hz}$ line noise and a $53 \mathrm{~Hz}$ artefact present in this dataset caused by the HPI coils. Time segments containing artefacts were identified by using generalized extreme studentized deviate method (GESD (Rosner, 1983)) at a significance level of 0.05 with a maximum number of outliers limited to $20 \%$ of the data on the standard deviation of the signal across all sensors in $1 \mathrm{~s}$ non-overlapping windows. The windows corresponding to outliers were excluded from all further analysis. Further denoising was applied using independent component analysis (ICA) using temporal FastICA across sensors (Hyvarinen, 1999). 62 independent components were estimated and components representing stereotypical artefacts such as eye blinks, eye movements, and electrical heartbeat activity were manually identified and regressed out of the data. Data then were filtered into three frequency bands $(\beta 13-30 \mathrm{~Hz}$, slow- $\gamma$ 30-60 Hz, mid- $\gamma 60-90 \mathrm{~Hz})$ and the following processing steps were performed separately for the three frequency bands.

Magnetometers and Planar-Gradiometers were normalized by computing the eigenvalue decomposition across sensors within each coil type and dividing the data by the smallest eigenvalue within each (Woolrich et al., 2011). Data were projected onto an $8 \mathrm{~mm}$ grid in source space (resulting in 3559 virtual sensors) using a Linearly Constrained Minimum Variance (LCMV) vector beamformer (Van Veen and Buckley, 1988; Woolrich et al., 2011). Beamformer weights were estimated across an $8 \mathrm{~mm}$ grid cast within the inner-skull of the MNI152 brain. A covariance matrix was computed across the whole time-course and was regularized to 50 dimensions using principal component analysis (PCA) rank reduction (Quinn et al., 2018). 
bioRxiv preprint doi: https//doi.org/10.1101/2021.06.16.448658; this version posted June 16, 2021. The copyright holder for this preprint (which was not certified by peer review) is the author/funder, who has granted bioRxiv a license to display the preprint in perpetuity. It is made available under aCC-BY-ND 4.0 International license.

Gamma and GABA in Human Motor Cortex

Zich \& Nowak et al.

2 Epochs were defined relative to the movement onset (movement offset for $\beta$ ERS) as 3 identified by surface EMG. To identify movement onset and offset EMG data were first highpass filtered at $10 \mathrm{~Hz}$. EMG data were then segmented from $-1 \mathrm{~s}$ to $3 \mathrm{~s}$ relative to the Go stimuli, and the envelope (root mean square, window = $80 \mathrm{~ms}$ ), computed. Using a nonoverlapping moving standard deviation (movement onset: window $=24 \mathrm{~ms}$, direction $=$ forward; movement offset: window $=120$ ms, direction = backwards) movement onset and offset were defined as the first window exceeding the threshold (three standard deviations of the EMG activity between $-600 \mathrm{~ms}$ to $-200 \mathrm{~ms}$ relative to Go stimuli). Trials were excluded when the envelope, the reaction time (i.e. time between Go stimuli and movement onset), or the movement time (i.e. time between movement onset and offset) were identified as outliers using GESD at a significance level of 0.05. This approach results in 45.59 (SD $=4.88$ ) out of 56 epochs per individual. MEG data were segmented from $-2 \mathrm{~s}$ to $2 \mathrm{~s}$ relative to movement onset (movement offset for $\beta$ ERD).

Time-frequency analysis was applied to single trials and virtual sensors using dpss-based multitaper (window $=1.6 \mathrm{~s}$, steps $=200 \mathrm{~ms}$ ) with a frequency resolution of $1 \mathrm{~Hz}$. Segments were baseline corrected ( $-1 \mathrm{~s}$ to $-0.5 \mathrm{~s}$, [ $-1.5 \mathrm{~s}$ to $-1 \mathrm{~s}$ for $\beta$ ERD]) using the mean baseline across all trials. This procedure results in trial-by-trial time-frequency decomposition for each of the 3559 virtual sensors. To detect the individual peak frequency within each frequency band only the virtual sensors within $M 1$, following the Desikan-Killiany atlas, $(N=92)$ were considered. Trial-wise movement-related power was obtained by averaging across time, i.e. from movement onset to movement offset (from movement offset to movement offset $+1 \mathrm{~s}$ for $\beta$ ERS) and then averaged across trials. The maximum (minimum for $\beta$ ERD) of the resulting twodimensional matrix containing the power between movement on- and offset across trials at each frequency within the frequency band at each virtual sensor was defined as an individual's power and defined the individual's peak frequency and virtual sensor (Fig. 1b).

To illustrate the spatial properties of movement-related responses we computed the movement-related power (as above, first averaging across time, i.e. from movement onset to movement offset [from movement offset to movement offset $+1 \mathrm{~s}$ for $\beta$ ERS] and then averaged across trials) at the individual's peak frequency for each of the 3559 virtual sensors. 
bioRxiv preprint doi: https://doi.org/10.1101/2021.06.16.448658; this version posted June 16, 2021. The copyright holder for this preprint (which was not certified by peer review) is the author/funder, who has granted bioRxiv a license to display the preprint in perpetuity. It is made available under aCC-BY-ND 4.0 International license.

a

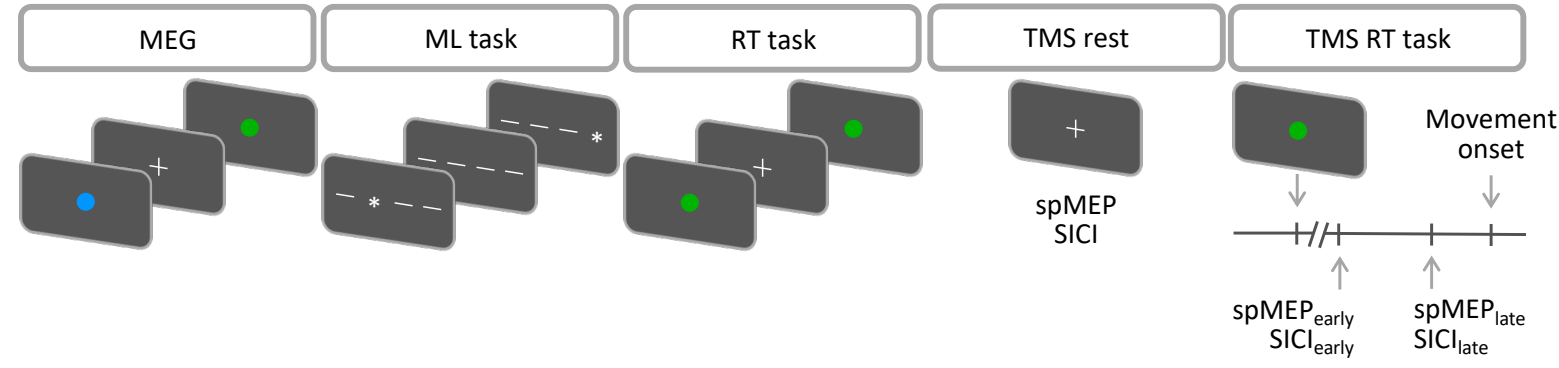

b
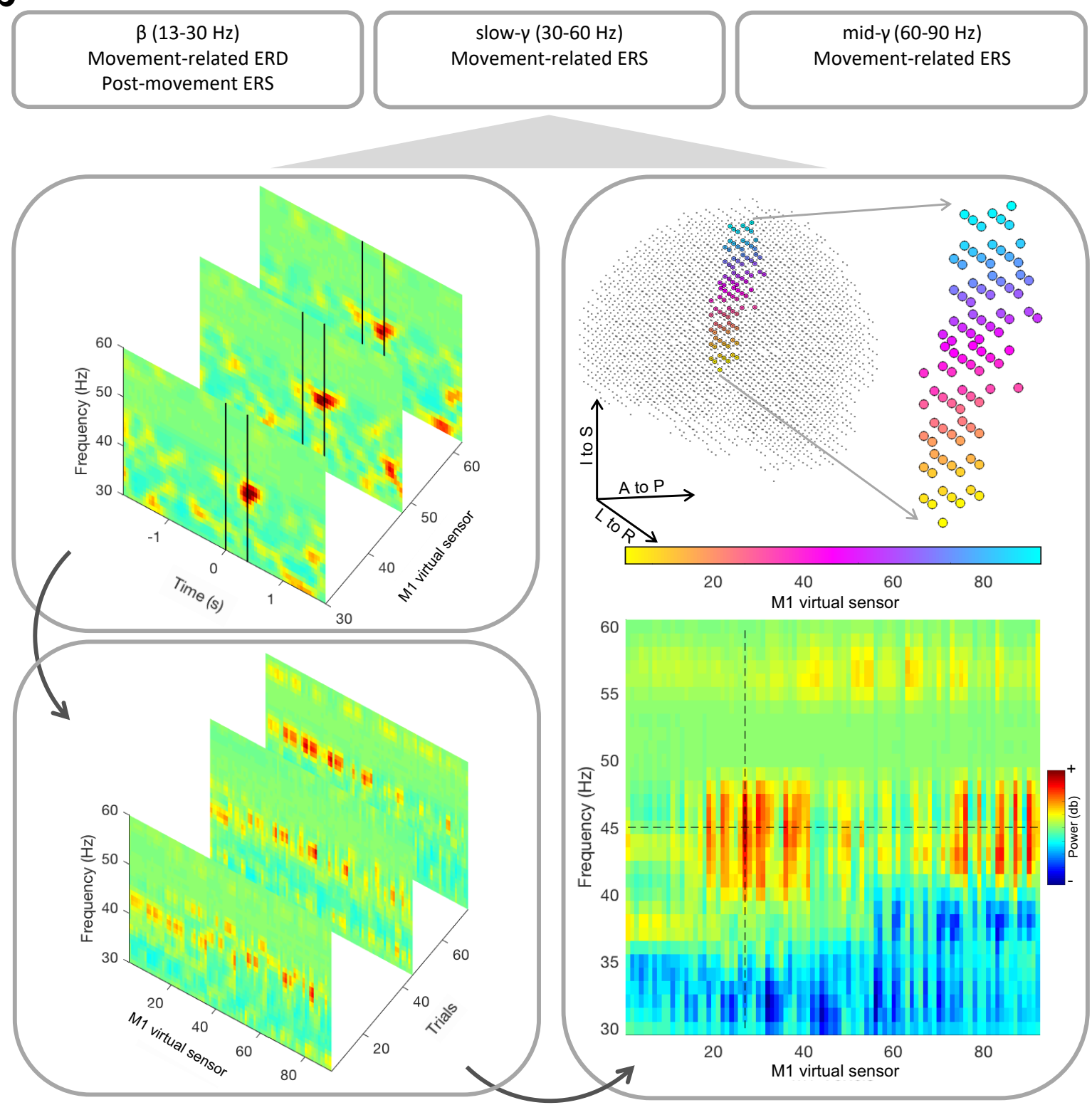

Fig.1 (a) Experimental timeline. MEG data were recorded while individuals performed a Go/NoGo task (70 trials). Each trial started with a preparation cue (blue circle, for $200 \mathrm{~ms}$ ), followed by a cue-stimulus interval (fixation cross, $1000 \mathrm{~ms}$ ) and the Go (green circle, $80 \%$ of the trials) or NoGo (red circle) cue. After the MEG participants performed a visually cued motor sequence learning (ML) task (4 fingers, 10-item sequence, 3 repeats per block, 15 blocks). Individuals also performed a simple response time (RT) task (20 trials) to determine their individual RT. Each trial started with a green circle indicating to perform an index finger abduction followed by a fixation cross indicating the inter-trial interval. TMS measures (single- 
bioRxiv preprint doi: https://doi.org/10.1101/2021.06.16.448658; this version posted June 16, 2021. The copyright holder for this preprint (which was not certified by peer review) is the author/funder, who has granted bioRxiv a license to display the preprint in perpetuity. It is made available under aCC-BY-ND 4.0 International license.

pulse MEP [spMEP] and short interval intracortical inhibition [SICI]) were performed at rest and during the RT task. During the RT task, spMEP and $\mathrm{SICl}$ were obtained at two different timings during movement preparation: an early time point ( $25 \%$ of mean RT, SpMEP early, $\mathrm{SICl}_{\text {early }}$ ) and a late time point (65\% of mean RT, spMEP late, $\mathrm{SICl}_{\text {late) }}$. (b) Pipeline used to identify the individuals' peak frequency for $\beta$ ERD, $\beta$ ERS, slow- $\nu$ ERS, mid- $\gamma$ ERS, exemplary for one individual for slow- $\gamma$ ERS. For each individual trial the power from movement onset to movement offset (movement offset to movement offset $+1 \mathrm{~s}$ for $\beta$ ERS), as determined by EMG and indicated by the black vertical lines, was averaged for each frequency band and virtual sensors within the M1 separately (top left). This resulted in movement-related power (post-movement-related power for $\beta$ ERS) for each frequency, M1 virtual sensor and trial (bottom left). The maximum (minimum for $\beta$ ERD) of the average across trials (right) indicates the individuals' power, peak frequency (dashed horizontal line) and virtual sensor within M1 (dashed vertical line). Virtual sensors are ordered based on $\mathrm{MNI}$ z-coordinates and colorcoded accordingly (e.g. small index $=$ yellow $=$ inferior).

\section{Motor learning data analysis}

To derive an accurate motor learning score, individual RTs (i.e. time from cue onset to the correct button press) were first evaluated. Anticipatory responses (i.e. those that occurred before the cue) and outliers (i.e. RTs outside of the mean value \pm 2 SD per each block) were discarded. A motor learning score was calculated for each individual as a percentage change from the RT in the first sequence block (block 2) to blocks 10-14, when the learning plateaued (Stagg et al., 2011). Thus, more negative motor learning scores represent better performance. One individual was excluded from this analysis due to noncompliance with instructions.

Response time task data analysis EMG data were analysed online using Signal software version 3.13 (Cambridge Electronic Design). RT was identified for each trial as the time interval between the Go signal and the onset of EMG activity recorded above the FDI muscle (i.e. $\mathrm{mV}$ first data point where EMG amplitude $>0.1 \mathrm{mV}$ ). The mean $\mathrm{RT}$ was then used in the remainder of that experimental session to calculate the timing of the pre-movement TMS pulses.

MEP data analysis

Trials were excluded if the test pulse alone failed to elicit a reliable MEP (amplitude $<0.1 \mathrm{mV}$ ), there was precontraction in the target FDI muscle (EMG amplitude $>0.1 \mathrm{mV}$ in the $80 \mathrm{~ms}$ preceding the pulse), or, for the pre-movement TMS measures, EMG onset coincided with TMS pulse or no response was made. The peak-to-peak amplitude for each MEP was then calculated. Any MEPs outside of the mean value \pm 2 SD for each condition for each block were 
1 excluded. Next, a single iteration of Grubbs' test with a significance level of 0.05 was

2 performed for each TMS condition separately and any significant outliers excluded.

3 Collectively, these rejection criteria resulted in the exclusion of $<5$ trials per individual in any condition. $\mathrm{SICl}$ and ICF were expressed as a ratio of the mean conditioned MEP amplitude to the mean unconditioned MEP amplitude. For the pre-movement data, the TMS measures were analysed separately for each pre-movement time point ( $25 \%$ and $65 \%$ RT).

\subsection{Statistical analysis}

9 All Frequentist statistics were conducted as implemented in SPSS version 25 (SPSS Inc, Chicago, IL, USA). As Bayesian inference allows multiple hypotheses to be tested and can calculate the probability that one hypothesis is true relative to another hypothesis, correlation analysis was performed using Bayesian inference (JASP, JASP Team 2019, version 0.11.1) with default priors after outlier removal. The Bayes factors (BFs) is the ratio of the likelihood of one particular hypothesis to the likelihood of another. We categorise BFs based using the heuristic classification scheme for $\mathrm{BF}_{10}$ (Lee and Wagenmakers, 2013, p.105; adjusted from Jeffreys, 1961). Thus, for example, $\mathrm{BF}_{10}=10-30$ denotes strong evidence, $\mathrm{BF}_{10}=3-10$ moderate, and $B F_{10}=1-3$ anecdotal evidence for $H_{1}$, while $B F_{10}=1 / 3-1$ denotes anecdotal, $B F_{10}=1 / 10-1 / 3$ moderate, and $\mathrm{BF}_{10}=1 / 30-1 / 10$ strong evidence for $\mathrm{H}_{0}$. Outliers were identified for each correlation separately by bootstrapping the Mahalanobis distance (Schwarzkopf et al., 2012). To statistically compare correlations, Fisher's z-transformation was applied to each correlation coefficient, resulting in normally distributed values $r^{\prime}$ with standard errors $s_{r^{\prime}}$. The null hypotheses $\left(r_{1}^{\prime}-r_{2}^{\prime}=0\right)$ were tested in R(psych) (Revelle, 2015) using Student $t$ test (Howell, 2011). Reported $p$-values are 2 -tailed. 
bioRxiv preprint doi: https://doi.org/10.1101/2021.06.16.448658; this version posted June 16, 2021. The copyright holder for this preprint (which was not certified by peer review) is the author/funder, who has granted bioRxiv a license to display the preprint in perpetuity. It is made available under aCC-BY-ND 4.0 International license.

Gamma and GABA in Human Motor Cortex

Zich \& Nowak et al.

\section{Results}

\subsection{MEG reveals expected ERD and ERS in the beta band}

Clear movement-related changes in power were observed in all three frequency bands $(\beta$, slow- $\gamma$, mid- $\psi$ ), characterized by different spectra-temporal-spatial properties. We observed a clear $\beta$ ERD during movement and a $\beta$ ERS after movement termination. In line with previous studies, the $\beta$ ERD started before movement onset, plateaued between movement onset and offset, and terminated after movement offset (Fig. 2a, bottom left). The mean $\beta$ ERD peak frequency was $19.33 \mathrm{~Hz}$ (range 15-26 Hz). There was moderate evidence for a lack of relationship between peak frequency and power $\left(r=0.011, \mathrm{BF}_{10}=0.22\right)$ across individuals. Again, consistent with prior observations, the $\beta$ ERS started after movement offset and lasted for roughly $1 \mathrm{~s}$ (Fig. 2a, bottom right). The mean $\beta$ ERS peak was $18.21 \mathrm{~Hz}$ (range 14-25 Hz). There was anecdotal evidence for a lack of relationship between peak frequency and power $\left(r=-0.284, \mathrm{BF}_{10}=0.74\right)$.

\subsection{Two distinct patterns of movement-related $\gamma$ activity}

We then wanted to investigate movement-related activity in the $\gamma$ bands. In the slow- $\gamma$ band we observed a strong ERS, which started after movement onset, reached its peak at the time of movement offset, and decreased after movement offset, suggesting that the slow- $\nu$ ERS was temporally aligned with movement offset (Fig. 2a, center left). The mean slow- $\gamma$ peak frequency was $43.06 \mathrm{~Hz}$ (range 35-57 Hz), and moderate evidence for a lack of relationship between peak frequency and power was found $\left(r=-0.034, \mathrm{BF}_{10}=0.22\right)$. In the mid- $\psi$ band we also observed an ERS. This ERS started at movement onset, reached its peak between movement onset and offset, and terminated around movement offset (Fig. 2a, top left), therefore showing a temporal alignment with movement, unlike the slow- $\nu$ ERS. The mean mid- $\gamma$ peak frequency was at $71.36 \mathrm{~Hz}$ (range $63-80 \mathrm{~Hz}$ ), and there was anecdotal evidence for a lack of relationship between peak frequency and power $\left(r=0.249, \mathrm{BF}_{10}=0.55\right)$.

To our knowledge, while movement-related slow- $\gamma$ has been reported previously (Crone et al., 1998; Szurhaj et al., 2006), its properties have not been fully characterised. We therefore sought to investigate whether this pattern of neural activity was distinct from the movementrelated $\beta$ ERS and mid- $\nu$ ERS. We performed four Bayesian pairwise correlations to test whether the peak frequency or power of the slow- $\gamma$ ERS was related to these measures 
bioRxiv preprint doi: https:/doi.org/10.1101/2021.06.16.448658; this version posted June 16, 2021. The copyright holder for this preprint (which was not certified by peer review) is the author/funder, who has granted bioRxiv a license to display the preprint in perpetuity. It is made available under aCC-BY-ND 4.0 International license.

Gamma and GABA in Human Motor Cortex

Zich \& Nowak et al.

1 derived from the $\beta$ ERS or mid- $\nu$ ERS (Fig. 2b). We found moderate evidence for a lack of

2 relationship between slow- $\nu$ ERS and $\beta$ ERS peak frequency $\left(r=-0.196, \mathrm{BF}_{10}=0.38\right)$ and

3 anecdotal evidence for a lack of relationship between slow- $\nu$ ERS and mid- $\nu$ ERS peak

4 frequency $\left(r=0.088, \mathrm{BF}_{10}=0.26\right)$. In terms of power, there was moderate evidence for a lack

5 of a relationship between slow- $\gamma$ ERS and $\beta$ ERS $\left(r=-0.019, \mathrm{BF}_{10}=0.22\right)$, but strong evidence

6 for a relationship between slow- $\nu$ ERS and mid- $\nu$ ERS $\left(r=0.514, \mathrm{BF}_{10}=12.61\right)$.
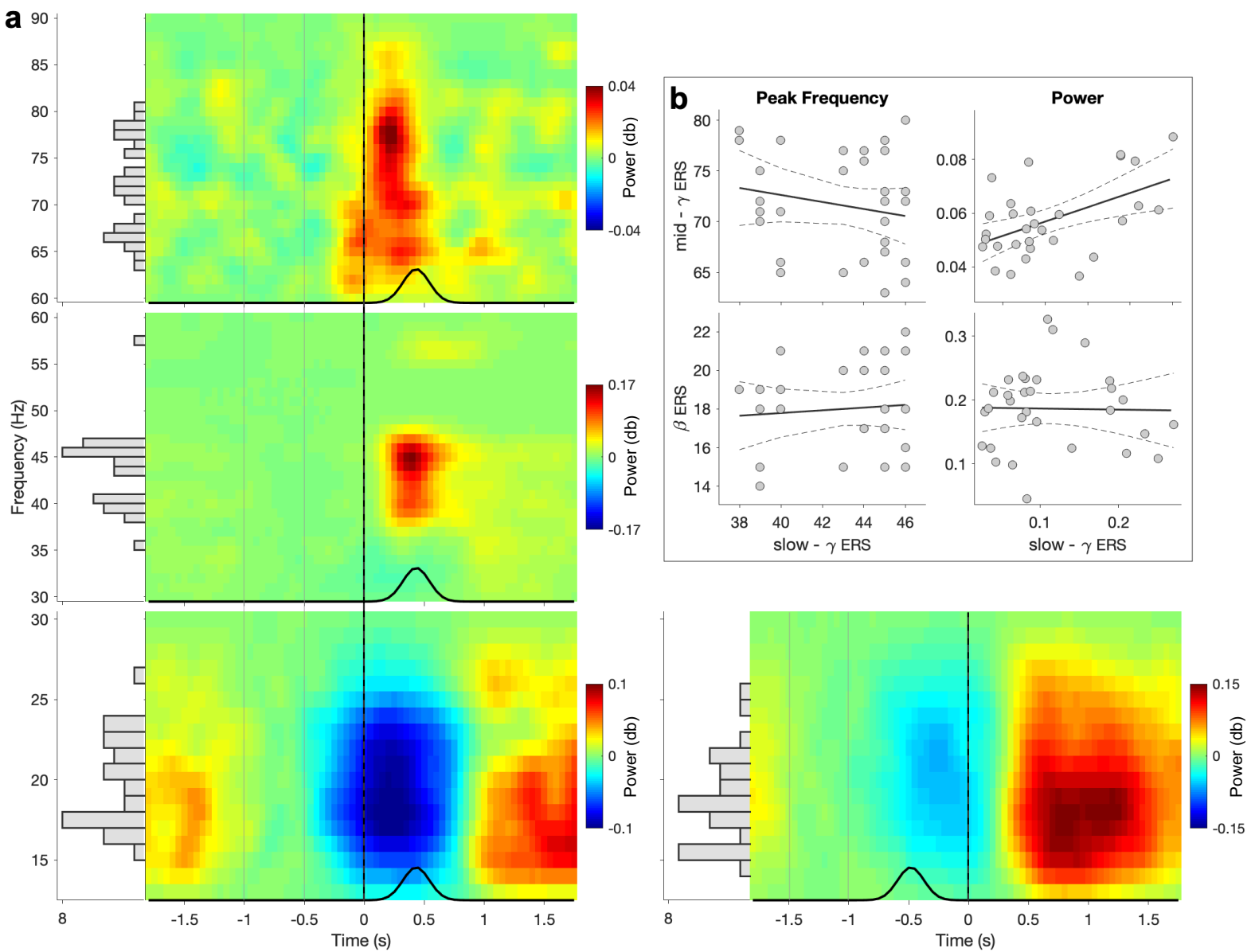

Fig.2 Temporal and spectral properties of movement-related responses. (a) Changes in power relative to baseline ( -1 to -0.5 s relative to movement onset $[-1.5$ to $-1 \mathrm{~s}$ relative to movement offset for $\beta$ ERS], as indicated by the grey vertical lines). Data are locked to movement onset (movement offset for $\beta$ ERS, as identified by EMG and highlighted by the black vertical line). Black line represents the distribution of movement offsets (movement onsets for $\beta$ ERS) of trials included in the analysis. Side panel histograms illustrate the distribution of individual peak frequency (bin size $=1 \mathrm{~Hz}$ ). (b) Correlations for peak frequency (left) and power (right) between slow $-\gamma$ ERS and $\beta$ ERS (bottom) as well as slow- $\nu$ ERS and mid- $\nu$ ERS (top). Dashed lines represent the $95 \%$ confidence intervals.

Next, we examined the spatial properties of the movement-related slow- $\nu$ ERS compared with the $\beta$ ERD, $\beta$ ERS and mid- $\gamma$ ERS. We considered the group-heatmaps of the peak virtual 
bioRxiv preprint doi: https://doi.org/10.1101/2021.06.16.448658; this version posted June 16, 2021. The copyright holder for this preprint (which was not certified by peer review) is the author/funder, who has granted bioRxiv a license to display the preprint in perpetuity. It is made available under aCC-BY-ND 4.0 International license.

Gamma and GABA in Human Motor Cortex

Zich \& Nowak et al.

1 sensors and power maps. In line with previous findings, the group-heatmaps of the peak

2 virtual sensors for $\beta$ ERD and $\beta$ ERS were relatively focal with the hotspot posterior and

3 relatively central on the superior-inferior axis within the M1 (Fig. 3a). In contrast, the hotspot

4 for the slow- $\gamma$ was more superior and central on the anterior-posterior axis. Finally, the

5 heatmap for the mid- $\nu$ was less focal, encompassing the hotspot of the $\beta$ and the slow- $\nu$

6 frequency range.

7

The spatial pattern of the power maps was qualitatively comparable for $\beta$ ERD, $\beta$ ERS and mid-

$\gamma$ with peaks in central on the superior-inferior axis and the anterior-posterior axis within M1

(Fig. 3b). In contrast, the spatial map of the slow- $\gamma$ was qualitatively more anterior within the

M1 and extended to frontal areas.

a

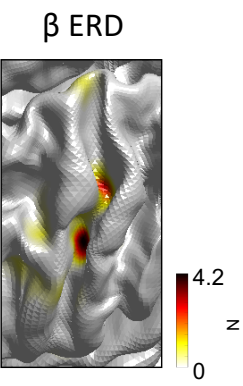

b

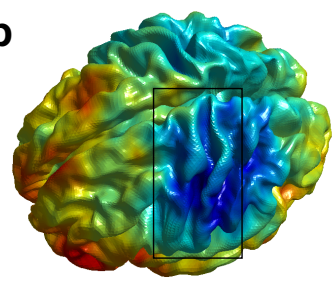

$\beta$ ERS
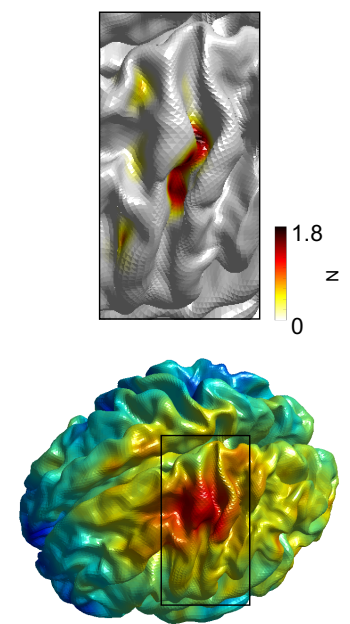

slow- $\gamma$ ERS
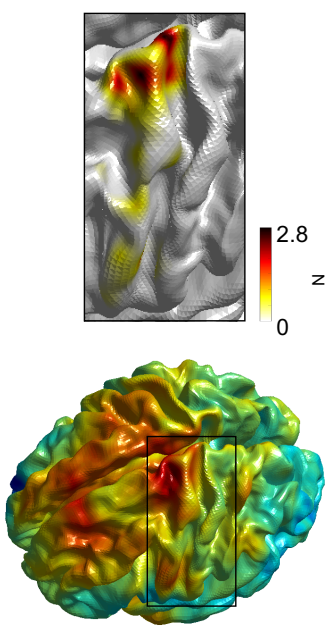

mid- $-~ E R S$
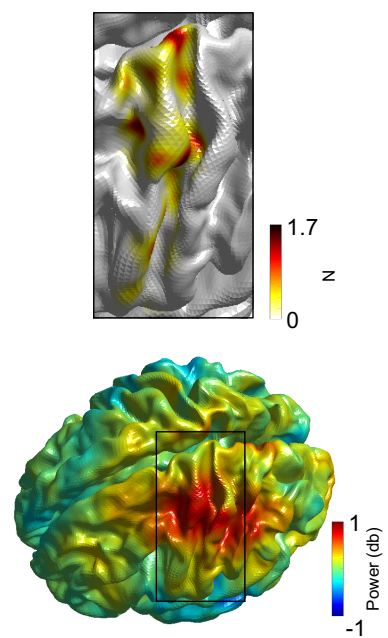

Fig.3 Spatial properties of movement-related responses. (a) Heatmap of the number of selected virtual sensors within M1. For visualisation data are interpolated. (b) Power maps, i.e. power averaged from movement onset to movement offset (movement offset to movement offset $+1 \mathrm{~s}$ ) at each of the of the 3559 virtual sensors at the individuals' peak frequency (i.e. frequency with strongest positive [negative for $\beta$ ERD] power change from baseline within M1).

\subsection{Slow- $\nu$ ERS peak frequency is related to individuals' GABA-A activity during} movement preparation

Next, we investigated the neurophysiological underpinnings of the movement-related activity we observed. In line with our hypothesis that movement-related activity in the $\gamma$ band is related to movement-related GABA-A activity, we found strong evidence for a positive relationship between pre-movement $\mathrm{SICl}$ amplitude and slow- $\gamma$ peak frequency $(r=0.677$, $\left.\mathrm{BF}_{10}=18.13\right)$. There was moderate evidence for a lack of relationship between pre-movement 
$1 \mathrm{SICl}$ amplitude and peak frequency in other bands ( $\beta$ ERD: $r=-0.010, \mathrm{BF}_{10}=0.29 ; \beta$ ERS: $r=$

$20.061, \mathrm{BF}_{10}=0.29 ;$ mid- $\gamma: r=0.07, \mathrm{BF}_{10}=0.295$, Fig. 4, left). The observed relationship between

3 pre-movement $\mathrm{SICl}$ and slow- $\gamma$ peak frequency was significantly different from the relationships observed in other bands $(\mathrm{SICl}$ and slow- $\gamma$ peak frequency vs $\mathrm{SICl}$ and $\beta$ ERD peak frequency: $z=-2.26, p=0.024 ; \mathrm{SICl}$ and slow $-\gamma$ peak frequency $\mathrm{vs} \mathrm{SICl}$ and $\beta$ ERS peak frequency: $z=-2.10, p=0.036 ; \mathrm{SICl}$ and slow- $\gamma$ peak frequency vs $\mathrm{SICl}$ and mid- $\gamma$ peak frequency: $z=-2.07, p=0.039)$.

Having demonstrated a significant relationship between pre-movement $\mathrm{SICl}$ and slow- $\gamma$ peak frequency, we then wished to explore the temporal specificity of this effect. Therefore, we investigated the relationship between pre-movement $\mathrm{SICl}$ and slow- $\gamma$ peak frequency, for $\mathrm{SICl}_{\text {early }}$ and $\mathrm{SICl}_{\text {late }}$ separately, in post-hoc analyses. There was anecdotal evidence for a positive relationship between slow- $\gamma$ peak frequency and GABA-A activity early in movement preparation $\left(\mathrm{SICl}_{\text {early }}, r=0.433, \mathrm{BF}_{10}=1.78\right)$ and strong evidence for a positive relationship between slow- $\gamma$ peak frequency and GABA-A activity late in movement preparation $\left(\mathrm{SICl}_{\text {late, }} r\right.$ $\left.=0.641, \mathrm{BF}_{10}=10.41\right)$. There was no significant different between these two correlations $(z=$ $-0.84, p=0.401)$. There were no significant correlations between the peak frequency of any band and subsequent motor learning.

\subsection{Mid- $-\gamma$ power correlates with subsequent motor learning}

Finally, we wished to investigate the behavioural importance of these movement-related signals.

Firstly, it was important to determine whether participants were able to learn the task. As expected, RT decreased significantly across successive sequence blocks $\left(F_{(14,336)}=9.015 ; p<\right.$ 0.001). In contrast, there was no significant difference in mean RT between the two random blocks $\left(t_{(32)}=0.885 ; p=0.383\right)$, whereas there was a significant difference between block 14 (the final learning block) and block 15 (the second random block) $\left(t_{(28)}=-6.899 ; p<0.001\right)$, suggesting that improvements in RT occurred via learning of a specific sequence and not generic skill learning. There was also no significant difference between the RT from blocks 10- 
bioRxiv preprint doi: https:/doi.org/10.1101/2021.06.16.448658; this version posted June 16, 2021. The copyright holder for this preprint (which was not certified by peer review) is the author/funder, who has granted bioRxiv a license to display the preprint in perpetuity. It is made available under aCC-BY-ND 4.0 International license.

Gamma and GABA in Human Motor Cortex

Zich \& Nowak et al.

1 In line with our hypothesis, we found moderate evidence for a negative relationship between

2 motor learning score and mid- $\gamma$ power $\left(r=-0.481, \mathrm{BF}_{10}=7.13\right.$, Fig. 4 right $)$, such that higher

3 mid- $\psi$ power was related to greater motor learning. There was moderate evidence for a lack

4 of relationship between motor learning score and power in other bands ( $\beta$ ERD: $r=0.166, B_{10}$

$5=0.33 ; \beta$ ERS: $r=-0.056, \mathrm{BF}_{10}=0.23$; slow $\left.-\gamma: r=-0.281, \mathrm{BF}_{10}=0.684\right)$. The observed relationship

6 between motor learning score and mid- $\psi$ power was different from the relationship between

7 motor learning score and $\beta$ ERD power $(z=-2.55, p=0.011)$ and $\beta$ ERS power $(z=-1.72, p=$

8 0.085). There were no significant relationships between the power in any band and SICl.

9
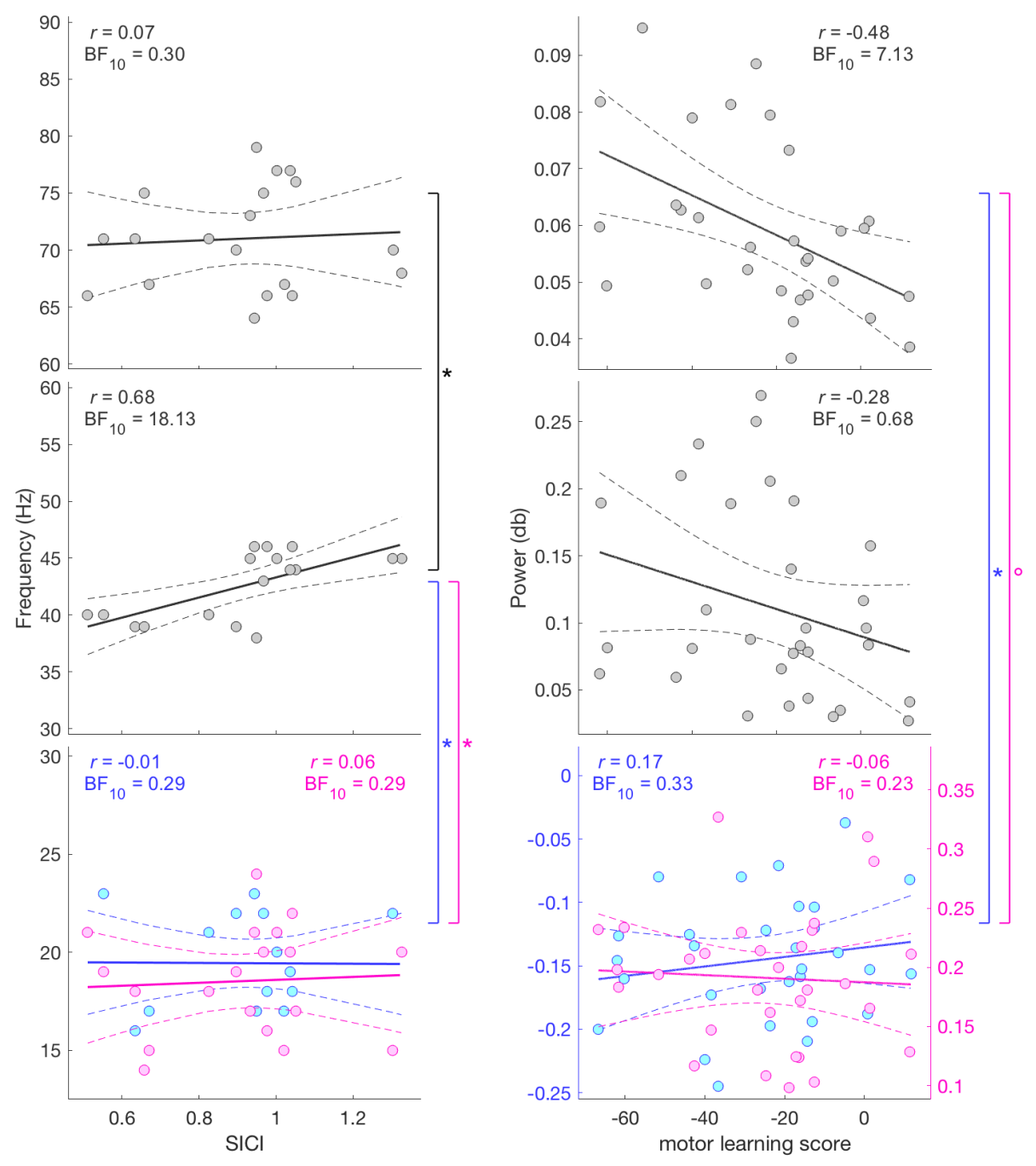

11 Fig.4 Relationship between MEG peak frequency and $\mathrm{SICl}$ amplitude (left) and MEG power and 12 motor learning score (right) for $\beta$ ERD (bottom blue), $\beta$ ERD (bottom pink), slow- $\gamma$ (middle) and 13 mid- $\gamma$ (top). Dashed lines represent the $95 \%$ confidence intervals. ${ }^{\circ} p<0.1,{ }^{*} p<0.5$. 
bioRxiv preprint doi: https://doi.org/10.1101/2021.06.16.448658; this version posted June 16, 2021. The copyright holder for this preprint (which was not certified by peer review) is the author/funder, who has granted bioRxiv a license to display the preprint in perpetuity. It is made available under aCC-BY-ND 4.0 International license.

Gamma and GABA in Human Motor Cortex

Zich \& Nowak et al.

\section{Discussion}

This work aimed to examine the physiological basis and functional significance of movementrelated M1 $\gamma$ activity. We identified two distinct patterns of movement-related $y$ activity in M1, characterised by different temporal-spectral-spatial properties. We went on to investigate the physiological correlates of these, and identified a correlation between M1 slow- $\nu$ peak frequency and pre-movement $\mathrm{SICl}$ amplitude in $\mathrm{M} 1$, such that individuals with a higher slow- $\gamma$ peak frequency showed less GABA-A activity. Finally, in line with previous work we found that a higher M1 mid- $\psi$ power was related to better individual performance in a motor learning task.

\subsection{Two distinct movement-related patterns of $\gamma$ activity}

Animal studies and human direct cortical recordings have suggested the presence of two distinct patterns of activity within the $\gamma$ band in $M 1$, but until now it has proved difficult to robustly separate them with transcranial approaches. By optimising our MEG analysis, i.e. separate beamformer for each sub-band and high-precision peak frequency/spatial location estimation, we have demonstrated the presence of two movement-related $\gamma$ activity patterns within M1.

Given the paucity of previous transcranial studies focussing on slow- $\gamma$ movement-related activity, we first examined whether the slow- $\nu$ activity seen here represented a distinct neural activity pattern, or was merely an extension of either post-movement $\beta$ ERS or movement mid- $\gamma$ ERS. We then reasoned that if the slow- $\nu$ ERS reflected activity within the same local microcircuits as either the post-movement $\beta$ ERS or movement mid- $\nu$ ERS we would expect to observe systematic relationships on a subject-by-subject basis between slow- $\gamma$ and $\beta$ or mid$\nu$. We only found a relationship between slow- $\nu$ ERS power and mid- $\gamma$ ERS power. The absence of other relationships add weight to the hypothesis that the slow- $\gamma$ ERS is a distinct movementrelated activity pattern but is in itself not conclusive. We therefore went on to investigate both the temporal and spatial domain of the slow- $\gamma$ ERS, demonstrating that it is dissociable from both the post-movement $\beta$ ERS and movement mid- $\nu$ ERS in both of these domains. Slow $-\gamma$ ERS appeared to be temporally aligned with the movement offset, rather than movement onset, like the mid- $\gamma$ ERS, or post-movement, like $\beta E R S$, and has a spatial distribution that is more frontal than either the mid- $\gamma$ ERS, which is more localised to M1 or the beta-ERS. 
bioRxiv preprint doi: https//doi.org/10.1101/2021.06.16.448658; this version posted June 16, 2021. The copyright holder for this preprint (which was not certified by peer review) is the author/funder, who has granted bioRxiv a license to display the preprint in perpetuity. It is made available under aCC-BY-ND 4.0 International license.

Gamma and GABA in Human Motor Cortex

Zich \& Nowak et al.

2 Taken together, the data suggest that two distinct patterns of movement-related $\gamma$ activity are

4.2 Slow- $\gamma$ activity likely arises from superficial cortical layers

A commonly held hypothesis states that activity in the lower cortical layers is predominantly slower than that in the more superficial layers (i.e. frequency-layer gradient), reflecting the different functional roles of superficial and deep layers. This is supported by animal studies in primary sensory areas (e.g. (Roopun et al., 2006; Buffalo et al., 2011; Spaak et al., 2012; Haegens et al., 2015)). Moreover, human laminar MEG showed that visual $\alpha$ activity and sensorimotor $\beta$ activity localise more to the white matter surface approximating infragranular origin than to the pial surface, while visual and sensorimotor $\gamma$ activity localise more to the pial surface approximating supragranular origin than to the white matter surface (Bonaiuto et al., 2018). However, there is also evidence challenging the frequency-layer gradient by suggesting deeper cortical layers as origin for $\gamma$ activity. For example, in the visual cortex of behaving mice, $Y$ activity has been linked to parvalbumin (PV)-positive GABAergic interneurons (Chen et al., 2017), which are most densely populated in layer V (Fagiolini et al., 2004; Sohal et al., 2009). Further, auditory in vitro work revealed two distinct $\gamma$ activities, 3045 and 50-80 Hz, originating in layer II/III and layer IV, respectively (Ainsworth et al., 2011). The precise neural basis of $\gamma$ activity in the primary $\mathrm{M} 1$, as opposed to primary sensory regions, has yet to be determined (Whittington et al., 2011). Translating the findings directly from studies performed in the sensory areas to M1 must be done with care, as the circuit organisation of M1 differs fundamentally from that of sensory areas, not least in that it is agranular, lacking a distinct layer IV (Shipp, 2005; Shipp et al., 2013).

To explore whether M1 movement-related $\beta$ and/or $\gamma$ activity arises from superficial cortical layers, we tested the relationship between $\beta$, slow $-\gamma$ and mid- $\gamma$ and $\mathrm{SICl}$ amplitude, a direct measure of local cortical GABA-A activity, quantified via TMS. TMS preferentially stimulates more superficial neurons, particularly at the intensities used here (Siebner et al., 2009). Further, computational modelling studies have demonstrated that TMS effects can be explained by activity within the canonical microcircuit, which includes layer II/III and layer V 
1 excitatory pyramidal cells, inhibitory interneurons, and cortico-cortical and thalamo-cortical 2 inputs (Di Lazzaro and Ziemann, 2013). We demonstrated a specific relationship between local 3 GABA-A activity and slow- $\gamma$ activity, which was not observed for either the $\beta$ or mid- $\gamma$ activity. Importantly, different microcircuits within M1 have distinct patterns of GABA-A receptor morphology in terms of their $\alpha$ subunits. $\mathrm{SICl}$ has been demonstrated to primarily represent activity within cortical microcircuits involving interneurons that express GABA-A receptors with $\alpha-2$ and $\alpha-3$ subunits, rather than $\alpha-1$ (Di Lazzaro et al., 2007). $\alpha-1$ subunits are found at highest density in layer $V$ of the healthy human $M 1$, whereas $\alpha-2$ subunits are more common in the superficial layers, and $\alpha-3$ are fairly equally distributed across the cortical layers (Freund, 2003; Petri et al., 2003).

In summary, the data presented here suggest that movement-related slow- $\gamma$ activity arises from neuronal circuits containing layer II/III interneurons. The functional role of movementrelated slow- $\gamma$ activity is less clear. Previous work has postulated that it may directly reflect motor output (Crone et al., 1998).

4.3 Mid- $\gamma$ activity may reflect activity in learning-related microcircuits In light of the significant correlation between slow- $\gamma$ and $\mathrm{SICl}$ amplitude the absence of the same relationship for mid- $\gamma$ could be interpreted in at least two ways. First, in human M1 slow$\gamma$ and mid- $\gamma$ steam both from superficial layers, but from different populations or microcircuits, with the one underlying slow- $\gamma$, but not mid- - , being GABAergic as measured using $\mathrm{SICl}$. This would be in line with the frequency-layer gradient reported in sensory areas (Roopun et al., 2006; Buffalo et al., 2011; Spaak et al., 2012; Haegens et al., 2015; Bonaiuto et al., 2018).

Second, while slow- $\gamma$ arises superficially mid- $\nu$ arises from deeper layers, such as layer $V$. This is in conformity with other animal work in sensory areas (Sohal et al., 2009; Ainsworth et al., 2011; Chen et al., 2017) and the supported by the functional role of M1 mid- $\gamma$. We demonstrated that the power of mid- $\gamma$ activity elicited by a simple movement predicted the ability to learn a motor skill on a subject-by-subject basis. This is in line with previous work. For example, we have shown that an individual's response to $75 \mathrm{~Hz}$ tACS relates to their ability to learn a subsequent motor skill (Nowak et al., 2017), and further, when amplitude 
1 modulated by an underlying theta pattern, improves motor learning in healthy adults (Akkad

2 et al., 2019). The finding of a specific relationship between mid- $\gamma$ activity and plasticity is

3 consistent with data from animal recordings suggesting that microcircuits containing $\alpha-1$

4 GABA-A synapses, predominantly found in the PV-rich layer $V$ in $M 1$, are a major neural

5 substrate for plasticity, at least in the visual cortex (Fagiolini et al., 2004). Together, the origin

6 of mid- $\gamma$ activity is not completely understood, but mid- $\gamma$ activity seems to play a role in motor

7 learning.

8

9

10

\subsection{Limitations}

This study used non-invasive recordings to indirectly study changes in movement-related activity in the motor cortex. While this approach provides an unrivalled ability to understand activity in the healthy human system, it has inherent limitations in terms of the conclusions we can draw. Specifically, here, it was difficult to accurately quantify activity around $50 \mathrm{~Hz}$ due to power line noise. In addition, due to an artefact caused by the HPI coils at 53 and $54 \mathrm{~Hz}$, we had to widen the standardly-employed line noise notch filter to $49-55 \mathrm{~Hz}$. This had direct implications on our assessment of the peak frequency of slow- $\gamma$ ERS.

\subsection{Conclusions}

The findings presented here allow us to create a theoretical framework for $\gamma$ activity in the human $\mathrm{M} 1$, as follows: there are two patterns of movement-related $\gamma$ activity in the human motor cortex (slow- $\gamma$ and mid- $\gamma$ ), with differential temporal, spectral and spatial properties. The frequency of movement-related slow- $\gamma$ activity is related to our neurophysiological measure of GABA-A activity, but does not play a direct role in motor plasticity in vivo. We conclude that slow- $\gamma$ arises from alpha-2 and alpha-3 GABA-A microcircuits in layer II/III. Mid$\gamma$ activity predicts motor learning, but weather it originates layer II/III or $\mathrm{V}$ is not yet clear. This framework draws together findings from this paper and the literature, and provides a number of hypotheses that can be directly tested. 
bioRxiv preprint doi: https:/doi.org/10.1101/2021.06.16.448658; this version posted June 16, 2021. The copyright holder for this preprint (which was not certified by peer review) is the author/funder, who has granted bioRxiv a license to display the preprint in perpetuity. It is made available under aCC-BY-ND 4.0 International license.

Gamma and GABA in Human Motor Cortex

Zich \& Nowak et al.

\section{Acknowledgements}

2 We thank Miles Whittington for helpful discussions on the functional role of gamma activity.

3

$4 \quad$ Funding

5 CJS holds a Sir Henry Dale Fellowship, funded by the Wellcome Trust and the Royal Society 6 (102584/Z/13/Z). MN is funded by the Wellcome Trust. MWW's research is supported by the 7 Wellcome Trust $(106183 / Z / 14 / Z, 215573 / Z / 19 / Z)$, and by the New Therapeutics in

\section{Data availability}

Data are available from the first authors and the last author upon request.

\section{Competing Interests}

No conflict of interest is declared.

\section{Author contributions}

$\mathrm{MN}$ and CJS designed the study. $\mathrm{MN}, \mathrm{EH}$ and $\mathrm{CZ}$ collected the data. $\mathrm{CZ}$ and $\mathrm{MN}$ analysed the data. AJQ and MWW provided assistance with data analysis. CJS supervised the project. CZ, $\mathrm{MN}$ and CJS wrote the manuscript and $\mathrm{EH}, \mathrm{AJQ}$ and MWW edited the manuscript.

\section{References}

Ainsworth M, Lee S, Cunningham MO, Roopun AK, Traub RD, Kopell NJ, Whittington MA (2011) Dual gamma rhythm generators control interlaminar synchrony in auditory cortex. J Neurosci 31:17040-17051.

Akkad H, Dupont-Hadwen J, Frese A, Tetkovic I, Barrett L, Bestmann S, Stagg CJ (2019) Increasing motor skill acquisition by driving theta-gamma coupling. 
bioRxiv preprint doi: https://doi.org/10.1101/2021.06.16.448658; this version posted June 16, 2021. The copyright holder for this preprint (which was not certified by peer review) is the author/funder, who has granted bioRxiv a license to display the preprint in perpetuity. It is made available under aCC-BY-ND 4.0 International license.

Gamma and GABA in Human Motor Cortex

Zich \& Nowak et al.

bioRxiv:2019.12.20.883926 Available at:

$$
\text { http://biorxiv.org/content/early/2019/12/20/2019.12.20.883926.abstract. }
$$

Bonaiuto JJ, Meyer SS, Little S, Rossiter H, Callaghan MF, Dick F, Barnes GR, Bestmann S (2018) Lamina-specific cortical dynamics in human visual and sensorimotor cortices. Elife 7:1-32.

Bragin A, Jando G, Nadasdy Z, Hetke J, Wise K, Buzsaki G (1995) Gamma (40-100 Hz) oscillation in the hippocampus of the behaving rat. J Neurosci 15:47-60.

Brainard D (1997) The Psychophysics Toolbox. Spat Vis 10:433-436.

Buffalo EA, Fries P, Landman R, Buschman TJ, Desimone R (2011) Laminar differences in gamma and alpha coherence in the ventral stream. Proc Natl Acad Sci U S A 108:1126211267.

Buzsáki G, Wang X-J (2012) Mechanisms of gamma oscillations. Annu Rev Neurosci 35:203225.

Canolty RT, Edwards E, Dalal SS, Soltani M, Nagarajan SS, Kirsch HE, Berger MS, Barbaro NM, Knight RT (2006) High gamma power is phase-locked to theta oscillations in human neocortex. Science (80- ) 313:1626-1628.

Carr MF, Frank LM (2012) A single microcircuit with multiple functions: State dependent information processing in the hippocampus. Curr Opin Neurobiol 22:704-708 Available at: http://dx.doi.org/10.1016/j.conb.2012.03.007.

Chen G, Zhang Y, Li X, Zhao X, Ye Q, Lin Y, Tao HW, Rasch MJ, Zhang X (2017) Distinct Inhibitory Circuits Orchestrate Cortical beta and gamma Band Oscillations. Neuron 96:1403-1418.e6 Available at: https://doi.org/10.1016/j.neuron.2017.11.033.

Cheyne D (2013) MEG studies of sensorimotor rhythms: a review. Exp Neurol 245:27-39. Cheyne D, Bells S, Ferrari P, Gaetz W, Bostan AC (2008) Self-paced movements induce highfrequency gamma oscillations in primary motor cortex. Neuroimage 42:332-342 Available at: http://www.ncbi.nlm.nih.gov/pubmed/18511304 [Accessed February 14, 2018].

Colgin LL (2015) Do slow and fast gamma rhythms correspond to distinct functional states in the hippocampal network? Brain Res 1621:309-315 Available at: http://dx.doi.org/10.1016/j.brainres.2015.01.005.

Colgin LL, Denninger T, Fyhn M, Hafting T, Bonnevie T, Jensen O, Moser MB, Moser El (2009) Frequency of gamma oscillations routes flow of information in the hippocampus. 
Nature 462:353-357.

Crone N, Sinai A, Korzeniewska A (2006) High-frequency gamma oscillations and human brain mapping with electrocorticography. Prog Brain Res 159:275-295.

Crone NE, Miglioretti DL, Gordon B, Lesser RP (1998) Functional mapping of human sensorimotor cortex with electrocorticographic spectral analysis. II. Event-related synchronization in the gamma band. Brain 121 ( Pt 1:2301-2315 Available at: http://www.ncbi.nlm.nih.gov/pubmed/9874481 [Accessed February 14, 2018].

Di Lazzaro V, Oliviero A, Saturno E, Dileone M, Pilato F, Nardone R, Ranieri F, Musumeci G, Fiorilla T, Tonali P (2005) Effects of lorazepam on short latency afferent inhibition and short latency intracortical inhibition in humans. J Physiol 564:661-668.

Di Lazzaro V, Pilato F, Dileone M, Profice P, Ranieri F, Ricci V, Bria P, Tonali PA, Ziemann U (2007) Segregating two inhibitory circuits in human motor cortex at the level of GABAA receptor subtypes: A TMS study. Clin Neurophysiol 118:2207-2214.

Fagiolini M, Fritschy JM, Löw K, Möhler H, Rudolph U, Hensch TK (2004) Specific GABAA Circuits for Visual Cortical Plasticity. Science (80- ) 303:1681-1683.

Fernández-Ruiz A, Oliva A, Nagy GA, Maurer AP, Berényi A, Buzsáki G (2017) Entorhinal-CA3 Dual-Input Control of Spike Timing in the Hippocampus by Theta-Gamma Coupling. Neuron 93:1213-1226.e5.

Freund TF (2003) Interneuron Diversity series: Rhythm and mood in perisomatic inhibition. Trends Neurosci 26:489-495.

Gaetz W, Edgar JC, Wang DJ, Roberts TPL (2011) Relating MEG measured motor cortical oscillations to resting $\gamma$-aminobutyric acid (GABA) concentration. Neuroimage 55:616621 Available at: https://pubmed.ncbi.nlm.nih.gov/21215806.

Gonzalez-Burgos G, Lewis DA (2008) GABA neurons and the mechanisms of network oscillations: implications for understanding cortical dysfunction in schizophrenia. Schizophr Bull 34:944-961.

Haegens S, Barczak A, Musacchia G, Lipton ML, Mehta AD, Lakatos P, Schroeder CE (2015) Laminar profile and physiology of the $\alpha$ rhythm in primary visual, auditory, and somatosensory regions of neocortex. J Neurosci 35:14341-14352. Howell D (2011) Statistical methods for psychology. Wadsworth: Cengage Learning. Hummel FC, Steven B, Hoppe J, Heise K, Thomalla G, Cohen LG, Gerloff C (2009) Deficient intracortical inhibition ( $\mathrm{SICl}$ ): During movement preparation after chronic stroke. 
Neurology 72:1766-1772.

Hyvarinen A (1999) Fast and robust fixed-point algorithms for independent component analysis. IEEE Trans Neural Networks 10:626-634 Available at: http://ieeexplore.ieee.org/document/761722/ [Accessed May 11, 2018].

Joundi RA, Jenkinson N, Brittain JS, Aziz TZ, Brown P (2012) Driving oscillatory activity in the human cortex enhances motor performance. Curr Biol 22:403-407 Available at: http://dx.doi.org/10.1016/j.cub.2012.01.024.

Kujirai T, Caramia M, Rothwell J, Day B, Thompson P, Ferbert A, Wroe S, Asselman P, Marsden C (1993) Corticocortical inhibition in human motor cortex. J Physiol (1993), 471:501-519.

Lasztóczi B, Klausberger T (2016) Hippocampal Place Cells Couple to Three Different Gamma Oscillations during Place Field Traversal. Neuron 91:34-40.

Miller KJ, Schalk G, Fetz EE, den Nijs M, Ojemann JG, Rao RPN (2010) Cortical activity during motor execution, motor imagery, and imagery-based online feedback. Proc Natl Acad Sci U S A 107:4430-4435.

Murase N, Duque J, Mazzocchio R, Cohen LG (2004) Influence of somatosensory input on motor function in patients with chronic stroke. Ann Neurol 55:400-409.

Muthukumaraswamy SD (2010) Functional Properties of Human Primary Motor Cortex Gamma Oscillations. J Neurophysiol 104:2873-2885 Available at: http://www.ncbi.nlm.nih.gov/pubmed/20884762 [Accessed February 14, 2018]. Muthukumaraswamy SD (2011) Temporal dynamics of primary motor cortex gamma oscillation amplitude and piper corticomuscular coherence changes during motor control. Exp Brain Res 212:623-633.

Nowak M, Hinson E, van Ede F, Pogosyan A, Guerra A, Quinn A, Brown P, Stagg CJ (2017) Driving Human Motor Cortical Oscillations Leads to Behaviorally Relevant Changes in Local GABA A Inhibition: A tACS-TMS Study. J Neurosci 37:4481-4492 Available at: http://www.jneurosci.org/lookup/doi/10.1523/JNEUROSCI.0098-17.2017.

Petri S, Krampfl K, Hashemi F, Grothe C, Hori A, Dengler R, Bufler J (2003) Distribution of GABAA receptor mRNa in the motor cortex of ALS patients. J Neuropathol Exp Neurol 62:1041-1051.

Pfurtscheller G, Lopes da Silva FH (1999) Event-related EEG/MEG synchronization and desynchronization: basic principles. Clin Neurophysiol 110:1842-1857. 
Revelle W (2015) psych: Procedures for Personality and Psychological Research.

Roopun AK, Middleton SJ, Cunningham MO, LeBeau FEH, Bibbig A, Whittington MA, Traub somatosensory cortex. Proc Natl Acad Sci U S A 103:15646-15650.

Rosner B (1983) Percentage Points for a Generalized ESD Many-Outlier Procedure.

Technometrics 25:165 Available at: https://www.jstor.org/stable/1268549?origin=crossref [Accessed May 11, 2018].

Schomburg EW, Fernández-Ruiz A, Mizuseki K, Berényi A, Anastassiou CA, Koch C, Buzsáki G Hippocampal Networks. Neuron 84:470-485.

Schwarzkopf DS, De Haas B, Rees G (2012) Better Ways to Improve Standards in BrainBehavior Correlation Analysis. Front Hum Neurosci 6:1-6.

Shipp S (2005) The importance of being agranular: a comparative account of visual and motor cortex. Philos Trans R Soc London Ser B, Biol Sci 360:797-814.

Shipp S, Adams RA, Friston KJ (2013) Reflections on agranular architecture: predictive coding in the motor cortex. Trends Neurosci 36:706-716.

Siebner HR, Hartwigsen G, Kassuba T, Rothwell JC (2009) How does transcranial magnetic stimulation modify neuronal activity in the brain? Implications for studies of cognition. Cortex 45:1035-1042 Available at: http://dx.doi.org/10.1016/j.cortex.2009.02.007.

Spaak E, Bonnefond M, Maier A, Leopold DA, Jensen O (2012) Layer-specific entrainment of gamma-band neural activity by the alpha rhythm in monkey visual cortex. Curr Biol 22:2313-2318 Available at: http://dx.doi.org/10.1016/j.cub.2012.10.020. 
bioRxiv preprint doi: https://doi org/10.1101/2021.06.16 448658. this version posted June 16, 2021. The copyright holder for this preprint (which was not certified by peer review) is the author/funder, who has granted bioRxiv a license to display the preprint in perpetuity. It is made available under aCC-BY-ND 4.0 International license.

Gamma and GABA in Human Motor Cortex

Zich \& Nowak et al.

1

36:6445-6458 Available at:

2

http://www.jneurosci.org/lookup/doi/10.1523/JNEUROSCl.1128-16.2016.

3

Swann NC, De Hemptinne C, Thompson MC, Miocinovic S, Miller AM, Gilron R, Ostrem JL, Chizeck HJ, Starr PA (2018) Adaptive deep brain stimulation for Parkinson's disease using motor cortex sensing. J Neural Eng 15.

6 Szurhaj W, Labyt E, Bourriez J-L, Kahane P, Chauvel P, Mauguière F, Derambure P (2006) Relationship between intracerebral gamma oscillations and slow potentials in the human sensorimotor cortex. Eur J Neurosci 24:947-954 Available at: http://www.ncbi.nlm.nih.gov/pubmed/16930422 [Accessed February 14, 2018].

Van Veen BD, Buckley KM (1988) Beamforming: A Versatile Approach to Spatial Filtering. IEEE ASSP Mag 5:4-24.

Whittington MA, Cunningham MO, LeBeau FEN, Racca C, Traub RD (2011) Multiple origins of the cortical gamma rhythm. Dev Neurobiol 71:92-106.

Woolrich M, Hunt L, Groves A, Barnes G (2011) MEG Beamforming using Bayesian PCA for Adaptive Data Covariance Matrix Regularisation. Neuroimage 57:1466-1479. 